Pomáhajúce profesie, Roč. 3, č. 1, 2020, 31-40

\title{
OSOBNOSTNÉ TENDENCIE MATKY A OSAMELOSŤ DIEŤAŤA
}

\author{
Miriama Hudáková1, Dominika Koreňová ${ }^{2}$ \\ 1Ústav aplikovanej psychológie FSVaZ UKF Nitra \\ ${ }^{2}$ Katedra psychologických vied FSVaZ UKF Nitra \\ mhudakova2@ukf.sk
}

\begin{abstract}
Abstrakt: Ciel'om štúdie bolo skúmanie vzt'ahu medzi interpersonálnymi tendenciami osobnosti matky v ponímaní Learyho interpersonálnej teórie a osamelost'ou diet'at'a. Výskumnú vzorku tvorilo 60 matiek $\left(\mathrm{M}_{\mathrm{vek}}=38,79 ; \mathrm{SD}_{\mathrm{vek}}=3,22\right)$ a 60 detí (32 dievčat, 28 chlapcov, $\left.\mathrm{M}_{\mathrm{vek}}=10,19 ; \mathrm{SD}_{\mathrm{vek}}=0,77\right)$. Na meranie osobnostných tendencií matky bol použitý Dotazník interpersonálnej diagnózy (ICL; LaForge, Suczek, 1955). Osamelost' diet'at'a bola meraná škálou UCLA Loneliness Scale (Russell, Peplau, Cutrona, 1980). Zistili sme negatívny vzt'ah medzi autokratickou a egocentrickou interpersonálnou tendenciou matky a osamelost'ou diet’at'a. V prípade ostatných interpersonálnych tendencií matky sa vzt'ah s osamelost'ou diet’at’a nepreukázal. Uvedené zistenia v štúdii diskutujeme.
\end{abstract}

Kl'účové slová: osobnost' matky, interpersonálne tendencie osobnosti, osamelost' diet'at'a

\section{1 ÚVOD}

Predkladaná štúdia zist'uje vzt’ah medzi interpersonálnymi tendenciami osobnosti matky a prežívanými pocitmi osamelosti diet'at'a. Pre skúmanie osamelosti sme sa rozhodli preto, že stúpa počet osamelých l'udí, pričom podl'a výskumných zistení (Berguno, Leroux, McAinsh, Shaikh, 2004; Asher, Hymel, Renshaw, 1984) sa osamelost' čoraz častejšie vyskytuje v prežívaní diet'at'a. Zamerali sme sa na skúmanie osamelosti u detí v strednom školskom veku. Pocit osamelosti môže súvisiet' $\mathrm{s}$ viacerými premennými. Na základe dôležitej úlohy matky v živote diet’at’a sa domnievame, že práve osobnost' matky patrí medzi významné premenné, ktoré by mohli zvyšovat' riziko prežívania osamelosti diet'at'a. Podporu nachádzame v literatúre a štúdiách (Ernst, Cacioppo, 1999; Richaud de Minzi, 2006), ktoré naznačujú, že niektoré charakteristiky osobnosti matky môžu mat' vplyv na osamelost' diet'at'a. Podl'a Behrensovej (1954) práve osobnost' matky ovplyvňuje emocionálny vývin diet’at’a. Podpora a úprimný záujem o diet’a, pozornost' a starostlivost', prejavy lásky a prijatia, zvyšujú kvalitu vzt'ahu medzi matkou a diet'at’om a znižujú riziko prežívania osamelosti. V štúdii skúmame osobnost' matky v ponímaní interpersonálnej teórie osobnosti T. Learyho a zist'ujeme vzt’ahy medzi jednotlivými interpersonálnymi tendenciami osobnosti matky a osamelost'ou diet'at'a.

\subsection{Osamelost'}

Osamelost' predstavuje nepríjemnú a znepokojujúcu emocionálnu reakciu jednotlivca na nesúlad medzi vzt’ahmi, ktoré má a vzt’ahmi, ktoré by chcel mat'. Dôležité je to, že ide o subjektívne prežívaný nesúlad, ktorý pocit’uje každý za iných podmienok (Perlman, Peplau, 1984). Podl'a Bootha (2000) môžeme osamelost' charakterizovat' ako nepríjemný mentálny a emocionálny stav, ktorý je sprevádzaný pocitmi izolácie a nedostatkom významnejších vzt’ahov s inými l'ud'mi. Osamelí l'udia zažívajú nepríjemný stres, cítia sa izolovane, prázdne, nedôležito a bezcenne. Tieto pocity pramenia z vnímania a uvedomenia si toho, že sociálne potreby jeho osoby nie sú naplnené 
v takej kvalite a kvantite ako potrebuje (Perlman, Peplau, Peplau, 1984). S osamelost'ou v škole sa stretlo až 80\% detí vo veku 9 až 13 rokov (Berguno, Leroux, McAinsh, Shaikh, 2004). Viac než 10\% detí porovnatel'ného veku uviedlo, že pocit'ujú osamelost' a sociálnu nespokojnost' ustavične alebo väčšinu času (Asher, Hymel, Renshaw, 1984). V období strednej dospelosti dochádza k poklesu výskytu osamelosti, avšak v období staroby opät' dochádza k nárastu skúseností s osamelost'ou (Pinquart, Sörensen, 2001).

\subsubsection{Osamelost' u detí v strednom školskom veku}

V štúdii sa zameriame na osamelost' detí stredného školského veku, pričom za dolnú hranicu pre toto vývinové obdobie sa podl'a Vágnerovej (2000) považuje 8-9 rokov a hornú hranicu 11-12 rokov. V období stredného školského veku zostáva rodina pre diet’a nad’alej najvýznamnejším sociálnym prostredím. Vzt’ahy školáka k rodičom sú stále silné, rodičia sú samozrejmou a dôležitou súčast'ou sveta diet'at'a. V strednom školskom veku sú rodičia zdrojom emocionálnej istoty a bezpečia (Oravcová, 2012). Prekopová (2004) poukazuje na to, že najmä matka hrá významnú úlohu v emocionálnom vývine diet’at’a. Z hl'adiska školy je toto vývinové obdobie charakteristické prechodom žiakov na druhý stupeň základnej školy. U žiakov postupne narastá potreba kontaktu s rovesníkmi. Diet'a potrebuje byt' rovesníckou skupinou akceptované a pozitívne hodnotené (Vágnerová, 2000; Oravcová, 2012). Výskumné štúdie Asher a Paquette (2003) ukázali, že vzt'ahy s rovesníkmi sú významným faktorom ovplyvňujúcim rozvoj osamelosti.

Na základe vyššie uvedeného konštatujeme, že pre diet'a v strednom školskom veku nadobúdajú dôležitú úlohu rovesníci, ktorí akceptáciou podporujú jeho emocionálnu vyrovnanost', avšak rodina (najmä matka) je pre diet’a stále najdôležitejším sociálnym prostredím, čo nás viedlo k výberu práve tejto výskumnej vzorky. Emocionálna istota a bezpečie, ktorú poskytuje rodina, umožňuje diet’at'u l’ahšie nadväzovanie vzt'ahov s rovesníkmi. Ak niektorá z týchto potrieb, či už emocionálna istota a bezpečie zo strany rodičov alebo akceptácia diet'at’a zo strany rovesníkov nie je naplnená, diet’a môže prežívat' pocit osamelosti (Vágnerová, 2000).

\subsection{Osobnost' v kontexte interpersonálnej teórie osobnosti T. Learyho}

Osobnost' funguje ako celok interindividuálne odlišných schopností a spája sa s vonkajšími prejavmi jednotlivca, čiže interpersonálnym správaním jednotlivca (Nakonečný, 1998). V predkladanej štúdii skúmame osobnost' matky pomocou interpersonálnej teórie osobnosti T. Learyho, ktorý charakterizuje osobnost' ako „mnohoúrovňový vzorec pozorovatel'ných, vedomých alebo skrytých interpersonálnych prejavov jednotlivca“ (Leary, 1957, str. 15). Interpersonálne správanie považuje za základný aspekt osobnosti a rozlišuje osem interpersonálnych diagnostických kategórií, medzi ktoré zarad’ujeme autokratickú, egocentrickú, agresívnu, podozrievavú, poníženú, hyperkonformnú, hyperafiliantnú a hyperprotektívnu tendenciu osobnosti (Leary, 1957). Jednotlivé typy interpersonálneho správania sa zarad'ujú na kontinuu od ich adaptívnej formy po formu maladaptívnu (Kožený, Ganický, 1976). Osem interpersonálnych osobnostných tendencií v nasledujúcom texte stručne charakterizujeme podl'a Koženého, Ganického (1976) a Svobodu (2010):

Autokratická tendencia osobnosti je charakteristická pre jednotlivcov, ktorí si získavajú rešpekt a úctu, ktorí sú ambiciózni a energickí a často oplývajú fyzickou alebo intelektuálnou silou. Adaptívna forma sa vyznačuje energickým správaním a autoritou, ktorá je daná schopnost'ami jednotlivca. Pri maladaptácii jednotlivec podlieha preorganizovanosti, niekedy pedantérii. Extrémna miera sa prejavuje autokratickým a diktátorským správaním

Egocentrická tendencia osobnosti sa vyznačuje predovšetkým orientáciou na vlastnú osobu. V adaptívnej forme sa tento spôsob správania prejavuje sebadôverou a nezávislost'ou. Maladaptívna 
forma je charakterizovaná sebeckým správaním a využívaním ostatných pre dosiahnutie vlastných ciel'ov.

Agresívna tendencia osobnosti sa prejavuje sociálne neprijatel'ným správaním sa k druhým l'udom, v ktorom prevládajú trestajúce, sarkastické a neoblomné postoje. $V$ adaptívnej forme ide o jednotlivca, ktorý jedná s ostatnými tvrdo a rázne. V maladaptívnej forme vzbudzuje prílišný rešpekt alebo znechutenú poddanost'.

Podozrievavá tendencia osobnosti je typická pre jednotlivcov, ktorí sa snažia zachovat’ si emocionálnu stabilitu vytvorením si odstupu medzi sebou a okolím. V adaptívnej forme sú charakterizovaní kritickost'ou a zdravou nedôverou, ktorá ich chráni pred sklamaním. V maladaptívnej forme majú sklon vyhýbat' sa vzt'ahom, ktoré sú založené na dôvere, láske a blízkosti s druhými.

Ponížená tendencia osobnosti je charakteristická slabost'ou, skromnost'ou a podradnost'ou. Adaptívna forma sa prejavuje manifestovanou skromnost'ou, plachost'ou, citovou rezervovanost'ou a schopnost'ou podriadit' sa. Maladaptívna forma sa prejavuje pasívnou poníženost'ou, submisívnost'ou a manifestovanou inferioritou.

Hyperkonformná tendencia osobnosti sa prejavuje závislost'ou a hyperkonformnost'ou. V adaptívnej forme má tento typ správania podobu obdivujúcej alebo dôvernej konformity, ktorá je prejavovaná adekvátne vzhl'adom na sociálnu situáciu. Maladaptívna forma je charakteristická bezhraničnou závislost'ou.

Hyperafiliantná tendencia osobnosti sa vyznačuje nápadným priatel’ským štýlom. Adaptívna forma sa prejavuje priatel'ským správaním a ochotou k spolupráci. V maladaptívnej forme sa jednotlivci snažia uspokojit' potreby ostatných, je pre nich vel'mi dôležité, aby boli okolím pozitívne prijímaní a udržali si kladné vzt'ahy.

Hyperprotektívna tendencia osobnosti je charakteristická tým, že jednotlivec sa javí ako rozumná, úspešná, ohl’aduplná, zrelá a samostatná osoba. V adaptívnej forme je hlavnou črtou jednotlivca zodpovedné a ohl'aduplné správanie. Maladaptácia sa prejavuje vyhýbaním sa prejavom agresivity alebo pasivity. Jednotlivec si praje, aby ho ostatní považovali za rozumného a zodpovedného. Zarad'ujeme sem hyperprotektívnych rodičov, hlavne matky s nadmerným materinským citom.

\subsection{Osobnost' matky a osamelost' diet'at'a}

Rola matky zohráva nezamenitel'nú rolu v telesnom a duševnom vývine diet'at’a (Vágnerová, 2000). Vzt'ah medzi matkou a diet'at'om sa formuje od najútlejšieho detstva. Na základe citovej väzby v detstve sa vytvára model, cez ktorý diet'a vníma a formuje sociálne vzt’ahy. Tento model ovplyvňuje nadväzovanie sociálnych vzt'ahov po celý život. Spôsob akým diet'a nadväzuje vzt'ahy s druhými ovplyvňuje jeho sociálnu spokojnost', a tá v ňom môže v prípade nespokojnosti vzbudzovat' pocity osamelosti (Rönkä, 2017). Výskumné štúdie, ktoré sa zamerali na vzt’ah medzi matkou a diet’at'om a následnou socializáciou našli prepojenia medzi záujmom o emócie diet'at’a a poskytovaním sociálnej opory zo strany rodiča, ktoré zlepšujú sociálne kompetencie diet’at’a a znižujú prežívanú osamelost' (Ernst, Cacioppo, 1999; Richaud de Minzi, 2006), pričom podl'a Behrensovej (1954) práve osobnost' matky ovplyvňuje emocionálny vývin diet'at'a. Preto, ako sme už uviedli v úvode, sa domnievame, že osobnost’ matky patrí medzi významné premenné, ktoré by mohli súvisiet' s prežívaním osamelosti diet’at’a. Vychádzajúc z uvedeného je ciel’om štúdie skúmanie vzt'ahu medzi osobnost'ou matky v ponímaní Learyho interpersonálnej teórie a osamelost'ou diet'at'a. Pre jednotlivé osobnostné tendencie matky vo vzt'ahu s osamelost'ou diet’at’a formulujeme v závislosti od podpory v literatúre výskumné hypotézy alebo otázky. 
Výskumná štúdia, ktorú uskutočnili Repetti, Taylor a Seeman (2005) potvrdila, že agresivita, nedostatočná podpora, akceptácia a prejavy lásky zo strany rodičov, výrazne ovplyvňujú rozvoj pocitu osamelosti u diet'at'a. Rokach (2004) zistila, že deti vyrastajúce v rodinnom prostredí, v ktorom je kladený dôraz na osobnostné vlastnosti, ktoré súvisia s vysokou výkonnost'ou, nezávislost'ou a ciel'avedomost'ou, môžu podliehat' vyššiemu riziku osamelosti. Správanie rodičov, ktoré prezentujú autori vo výskumných štúdiách nachádzame v charakteristike autokratickej a agresívnej interpersonálnej osobnostnej tendencie, a preto predpokladáme pozitívny vzt'ah medzi autokratickou a tiež agresívnou tendenciou osobnosti matky a osamelost'ou diet'at'a.

Zilboorg (1938) zistil, že osamelost' diet’at’a môže vzniknút' dôsledkom narcizmu matky, ktorý sa vyznačuje predovšetkým orientáciou na vlastnú osobu. Egocentrický jednotlivec má často sklon $\mathrm{k}$ narcizmu (Svoboda, 1999) a preto v nadväznosti na toto zistenie predpokladáme pozitívny vzt'ah medzi egocentrickou tendenciou osobnosti matky a osamelost'ou diet'at'a.

Vo výskumných štúdiách Ernst, Cacioppo (1999) a Richaud de Minzi (2006) bolo zistené, že kladné vyjadrovanie emócií, záujem o emócie diet’at’a, taktiež vrelost' rodičov a poskytovanie sociálnej opory najmä zo strany matky zlepšuje sociálne kompetencie diet’at’a a znižuje prežívanú osamelost'. Správanie rodičov, ktoré vo výskumných štúdiách súviselo s osamelost'ou diet’at’a nachádzame $\mathrm{v}$ charakteristike hyperafiliantnej interpersonálnej osobnostnej tendencie a preto predpokladáme negatívny vzt'ah medzi hyperafiliantnou tendenciou osobnosti matky a osamelost'ou diet'at'a.

V prípade ostatných interpersonálnych osobnostných tendencií sme nenašli dostatočný podklad v literatúre pre stanovenie hypotéz o ich vzt'ahu s osamelost'ou diet'at'a. Preto ostávame na úrovni otázky a pýtame sa, či existuje vzt'ah medzi poníženou, podozrievavou, hyperkonformnou a hyperprotektívnou osobnostnou tendenciou matky a osamelost'ou diet'at'a?

\section{METÓDY}

\subsection{Výskumná vzorka}

Výskumnú vzorku tvorilo spolu 120 respondentov, z toho 60 matiek $\left(\mathrm{M}_{\mathrm{vek}}=38,79 ; \mathrm{SD}_{\mathrm{vek}}=3,22\right)$ a 60 detí (32 dievčat, 28 chlapcov, $\mathrm{M}_{\mathrm{vek}}=10,19 ; \mathrm{SD}_{\mathrm{vek}}=0,77$ ). Pri výbere výskumnej vzorky sme použili príležitostný výber. Výskumu sa zúčastnilo 24 žiakov základnej školy v Plešivci a 36 žiakov základnej školy vo Zvolene spolu so svojimi matkami. Prostredníctvom žiakov sme rodičom poslali informovaný súhlas s testovaním ich diet'at'a. Súčasne sme im poslali vysvetlenie zámeru výskumu, v ktorom ich žiadame o spoluprácu a Dotazník interpersonálnej diagnózy (ICL), ktorý vypíňali matky. Následne sme požiadali žiakov, ktorých rodičia podpísali informovaný súhlas s účast’ou ich diet'at'a na testovaní, aby vyplnili dotazník UCLA, ktorým sme zist'ovali osamelost' diet’at’a.

\subsection{Meracie nástroje}

Dáta pre výskum sme získali prostredníctvom dvoch meracích nástrojov. Pomocou Dotazníka Interpersonálnej diagnózy (ICL) sme merali interpersonálne tendencie osobnosti matky. Osamelost' diet'at'a sme merali pomocou UCLA Loneliness Scale.

\section{Dotazník interpersonálnej diagnózy (Interpersonal Checklist - ICL)}

Dotazník ICL (Laforge, Suczek, 1955) vznikol na základe Learyho interpersonálnej teórie osobnosti. Pozostáva zo 128 položiek, ktoré sú formulované ako adjektíva. Jednotlivé tvrdenia opisujú rôzne spôsoby správania jednotlivcov vo vzájomných vzt'ahoch. Príkladom položky je „Vie byt' priamy a otvorený“. Dotazník zist'uje 8 interpersonálnych tendencií osobnosti popísaných v kap. 1.2. Úlohou respondentov je v záznamovom hárku zaškrtávat' tvrdenia, o ktorých sa domnievajú, že ich 
charakterizujú. V štúdii sme použili slovenskú verziu dotazníka, ktorého autormi sú Kožený a Ganický (1976).

UCLA Loneliness Scale (Russell, Peplau, Cutrona, 1980)

Škála obsahuje 20 položiek, ktoré hodnotia respondentov subjektívny pocit osamelosti a spokojnost' so sociálnymi vzt'ahmi. Položky sú formulované ako otázky, napríklad „Ako často máte pocit, že sa nemáte na koho obrátit'? Respondenti sa vyjadrujú na štvorbodovej Likertovej stupnici od (1) nikdy po (4) vždy. Vyššiu mieru osamelosti predstavuje vyššie celkové skóre. V dotazníku nie je použitý pojem osamelost', čím môže byt' zabezpečené adekvátnejšie zist'ovanie skutočnej miery osamelosti. Pôvodná validizačná štúdia potvrdila vysokú validitu a reliabilitu škály (Russell, 1996). V našich dátach dosiahol Cronbachov koeficient alfa hodnotu $\alpha=0,78$, čo poukazuje na adekvátnu vnútornú konzistenciu škály.

\section{3 Štatistická analýza dát}

Štatistickú analýzu dát sme uskutočnili v programe IBM SPSS Statistics 21. Výber štatistických testov sme volili na základe distribúcie získaných dát. Všetky premenné okrem egocentrickej osobnostnej tendencie mali normálne rozloženie a preto sme na zist'ovanie vzt’ahov medzi nimi použili Pearsonov korelačný koeficient. V prípade egocentrickej osobnostnej tendencie sme na zist'ovanie jej vzt'ahu s osamelost'ou použili neparametrický Spearmanov korelačný koeficient.

\section{VÝSLEDKY}

Korelovali sme jednotlivé interpersonálne tendencie osobnosti matky s osamelost'ou diet'at'a. Zistené výsledky prezentujeme v tabul'ke 1.

Tabul'ka 1 Korelácie medzi interpersonálnymi tendenciami osobnosti matky a osamelost'ou diet'at'a

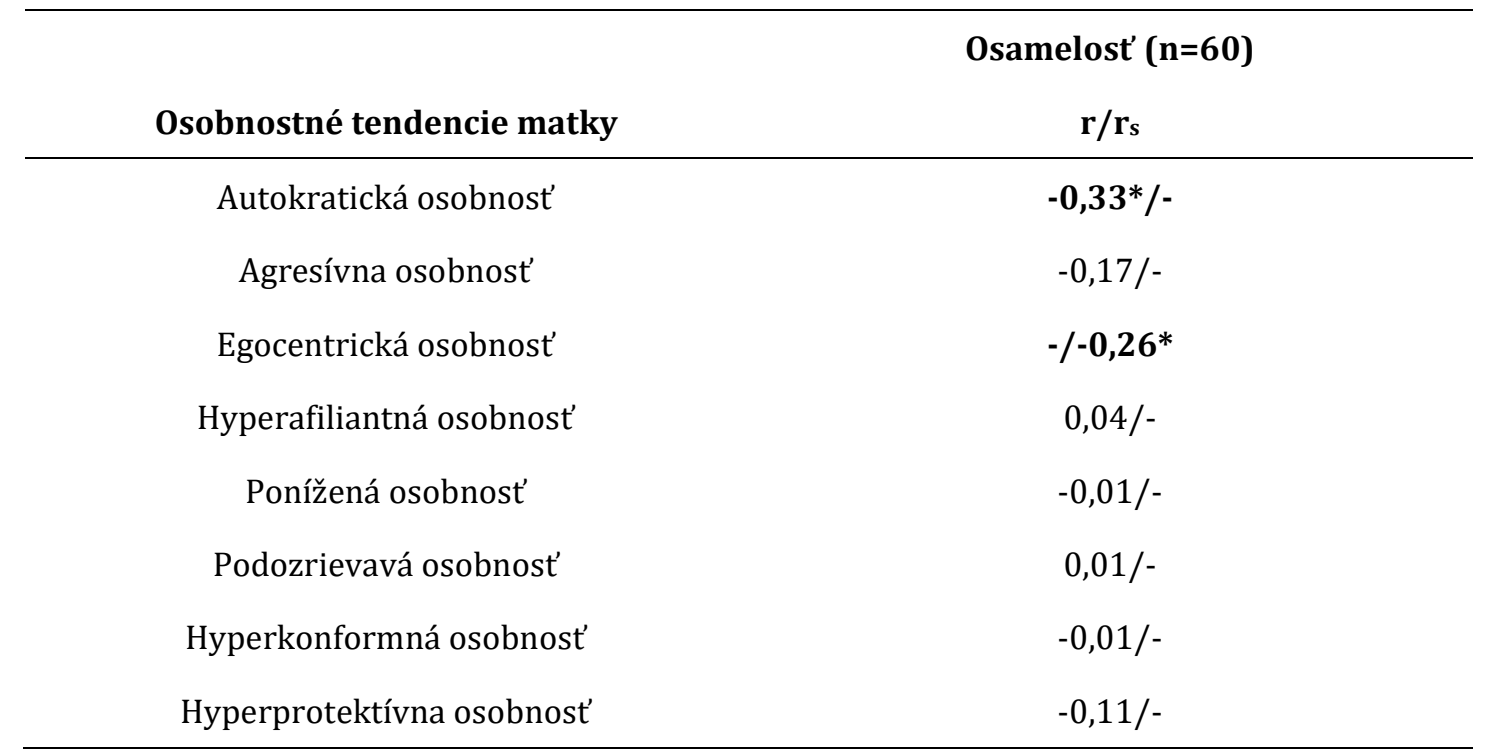

Legenda: $n$ - počet respondentov; $r$ - Pearsonov korelačný koeficient; $r_{s}-$ Spearmanov korelačný koeficient; * $-p<0,05$ 
Zistili sme štatisticky významný negatívny vzt’ah medzi autokratickou osobnostnou tendenciou matky a osamelost'ou diet'at'a a medzi egocentrickou osobnostnou tendenciou matky a osamelost'ou diet'at'a. V prípade autokratickej osobnostnej tendencie išlo o stredne silný vzt'ah a v prípade egocentrickej osobnostnej tendencie o slabý vzt’ah s osamelost'ou diet’at'a. Oba zistené vzt’ahy majú opačný smer ako sme predpokladali, čo nepotvrdzuje naše hypotézy. Medzi ostatnými osobnostnými tendenciami matky (agresívnou, hyperafiliantnou, poníženou, podozrievavou, hyperkonformnou a hyperprotektívnou tendenciou) a osamelost'ou diet'at'a sme nezistili štatisticky významné vzt’ahy.

\section{DISKUSIA}

Ciel'om štúdie bolo skúmat' vzt’ah medzi osobnost'ou matky v ponímaní interpersonálnej teórie T. Learyho a osamelost'ou diet’at'a. Výsledky o vzt'ahu medzi jednotlivými osobnostnými tendenciami matky a osamelost'ou diet'at'a v nasledujúcom texte diskutujeme.

Predpokladali sme, že medzi autokratickou interpersonálnou tendenciou osobnosti matky a osamelost'ou diet'at’a bude pozitívny vzt’ah na základe výskumu Rokach (2004), ktorá zistila vyššiu mieru prežívanej osamelosti u tých detí, ktoré vyrastajú v rodinnom prostredí, v ktorom sa kladie dôraz na osobnostné vlastnosti, ktoré súvisia s vysokou výkonnost'ou, nezávislost'ou, ciel'avedomost’ou a perzistenciou. Autokratická matka podl’a Varhol'ákovej (2014) málo dbá na individuálne potreby a osobitosti diet’at’a. Často kladie diet’at’u neprimerané požiadavky, ktorých následné nesplnenie vedie $\mathrm{k}$ negatívnemu hodnoteniu. Podl'a autorky prísna autokratická tendencia osobnosti matky výrazne zasahuje do emocionálnej sféry diet’at'a a vedie k vysokej emocionálnej citlivosti. Naše zistenie však poukazuje na stredne silný negatívny vzt’ah medzi autokratickou osobnostnou tendenciou matky a osamelost'ou diet'at’a, čo značí, že čím je matka autokratickejšia, tým je diet’a menej osamelé. Vysvetlenie tohto výsledky ponúkajú Vališová a kol. (1999) a Nolting a Paulus (1992), podl'a ktorých autoritatívny výchovný štýl a správanie rodičov diet'at'u nepoškodzuje, vyžaduje od detí, aby sa správali spoločensky a rozumne. Domnievame sa teda, že adaptívna forma autokratickej osobnosti vyznačujúca sa energickým správaním a autoritou, ktorá je daná schopnost’ami jednotlivca (Ganický, Kožený, 1976; Svoboda, 2010), môže byt' pre diet'a aj prospešná. Navyše Širǔček (2001) poukazuje na to, že v rodinnom prostredí predovšetkým otec uplatňuje autokratické interpersonálne tendencie, je tým, kto trestá a kladie nároky.

Pri agresívnej interpersonálnej tendencii osobnosti matky sme predpokladali, že bude v pozitívnom vzt'ahu k osamelosti diet’at’a, pričom sme sa opierali o štúdiu Repetti, Taylora a Seemana (2005), ktorá uvádza, že rodinné prostredie, v ktorom sa vyskytujú prejavy agresie, nedostatočná podpora, pozornost' a prejavy lásky zo strany rodičov majú negatívny vplyv na diet'a a predstavujú významný faktor, ktorý ovplyvňuje rozvoj osamelosti. Naše zistenia však naznačujú, že agresívna osobnostná tendencia matky nemá vzt’ah k osamelosti diet'at'a. Dôvodom by mohlo byt' postupné dospievanie, počas ktorého dochádza k zmenám v tom, čo diet'a očakáva od rodičov a v tom, čo očakáva od rovesníkov (Asher, Paquette, 2003). Macek (2003) vymedzuje prvú fázu dospievania medzi 10 až 13 rokom. Počas nej dochádza k postupnej emancipácii diet’at’a od rodiny a narastá význam rovesníckych vzt'ahov (Vágnerová, 2000). Je možné, že ak diet’a dostáva oporu a prejavy akceptácie od rovesníkov, nemuselo vykazovat' vyššiu osamelost' v našom výskume, napriek vyššej agresívnej osobnostnej tendencii matky. Osamelost' totiž môžeme podl'a Weissa (1973) delit' na dva kvalitatívne odlišné a navzájom nezávislé typy spôsobené rozličnými príčinami. Emocionálna osamelost' vzniká v prípade absentovania blízkeho dôverného vzt'ahu s osobou poskytujúcou emocionálnu oporu, porozumenie, blízkost', z čoho vyplýva, že môže íst' o nedostatočnú kvalitu citovej väzby k významnej osobe (Mikulincer, Shaver 2017). Na druhej 
strane sociálna osamelost’ pramení zo sociálnej izolácie, je spôsobená neúspešnou integráciou do sociálnej siete (Výrost, Slaměník, 2001). My sme v štúdii skúmali osamelost' ako komplexný subjektívne prežívaný nepríjemný stav. Je možné, že ak by sme sa zamerali na emocionálnu a sociálnu osamelost' samostatne, dopracovali by sme sa k inému výsledku. Možno práve emocionálna osamelost', na rozdiel od sociálnej, resp. v našom prípade komplexne skúmanej osamelosti by mohla mat' súvis s agresívnou osobnostnou tendenciou matky, nakol'ko práve emocionálny typ osamelosti sa týka dôverného blízkeho vzt’ahu a kvality citovej väzby s významnou osobou.

V prípade egocentrickej osobnostnej tendencie matky sme predpokladali, že bude v pozitívnom vzt'ahu s osamelost'ou diet’at'a na základe zistenia Zilboorga (1938), podl'a ktorého osamelost' diet'at'a môže vzniknút' dôsledkom narcizmu matky, pričom egocentrický jednotlivec má často sklon k narcizmu (Svoboda, 1999). Naše výsledky daný predpoklad nepotvrdili. Zistili sme síce slabý, ale negatívny vzt'ah medzi egocentrickou osobnostnou tendenciou matky a osamelost'ou diet’at’a. Vysvetlenie nášho výsledku môžu poskytnút' Donaldson-Pressman a Pressman (1994), ktorí tvrdia, že narcistická matka je schopná dosiahnut' väzbu dôvery a pripútanosti k diet’at'u, pretože potreby diet'at’a v strednom školskom veku predstavujú pre narcistickú matku len vel'mi malé riziko, ktoré ohrozuje jej nadradenú pozíciu. Diet’a teda nemusí pocit’ovat' zvýšenú mieru osamelosti, nakol'ko mu tento dôverný blízky vzt’ah nechýba.

Hyperafiliantná osobnostná tendencia matky mala podl’a nášho predpokladu negatívne súvisiet' s osamelost'ou diet'at'a. Opierali sme sa o výskumné zistenia autorov Ernst, Cacioppo (1999) a Richaud de Minzi (2006). Títo autori zistili, že ak rodičia kladne vyjadrujú svoje emócie, taktiež majú záujem o emócie diet’at’a, poskytujú mu vrelost' a oporu, tak zlepšujú sociálne kompetencie diet'at'a a znižujú možnú prežívanú osamelost'. Kusý $(2015,2018)$ dokonca spája hyperafiliantnú osobnostnú tendenciu spoločne s kooperatívnou, zodpovednou a hyperprotektívnou tendenciou s prosociálnou osobnost'ou. Náš predpoklad sa nepotvrdil, ked’že sme nezistili vzt'ah medzi hyperafiliantnou osobnostnou tendenciou matky a osamelost'ou diet’at'a. Vychádzali sme zo štúdií, ktoré sa zameriavali na oboch rodičov, avšak Brisch (2012) hovorí, že u matiek sa môžeme stretnút' s tým, že si chcú diet’a k sebe píliš pripútat', čím vzniká riziko vytvorenia príliš úzkej väzby, kde diet'a nemá dostatočný priestor na to, aby si regulovalo správanie samo, čím sú frustrované jeho potreby explorácie a diet’a môže prežívat' negatívne emócie. Na základe príliš úzkeho puta medzi matkou a diet'at'om sa domnievame, že matka môže diet'at'u zabraňovat' v socializácii. Diet'a môže mat’ citovú väzbu s matkou dostatočne uspokojenú avšak bez akceptácie sociálnou skupinou sa môže cítit' osamelé (Výrost, Slaměník, 2001).

Čo sa týka ostatných interpersonálnych tendencií osobnosti, teda poníženej, podozrievavej, hyperkonformnej a hyperprotektívnej, nemali sme vopred stanovený predpoklad o ich vzt'ahu k osamelosti diet'at'a. Chceli sme zistit', či s osamelost'ou diet'at’a súvisia. Naše výsledky poukazujú na to, že zmienené osobnostné tendencie matky nemajú vzt'ah kosamelosti diet’at’a ako komplexného subjektívne prežívaného nepríjemného stavu a pocitu izolácie. Ako sme už uviedli vyššie, uvažujeme však nad tým, že by bolo možné dopracovat' sa k iným výsledkom, ak by sme na osamelost' nenahliadali komplexne, ale zamerali by sme sa na emocionálnu a sociálnu osamelost' samostatne. Pri sociálnej osamelosti ide o neúspešnú integráciu do sociálnej siete (Výrost, Slaměník, 2001), kde pri jej prežívaní významnejšiu rolu môžu zohrávat' rovesníci. Na druhej strane emocionálna osamelost' vzniká v prípade absentovania blízkeho dôverného vzt'ahu a pri nedostatočnej kvalite citovej väzby kvýznamnej osobe (Mikulincer, Shaver 2017). Preto sa domnievame, že práve pri emocionálnom type osamelosti, na rozdiel od sociálnej osamelosti, hrá významnejšiu rolu matka, a tento typ osamelosti by tak mohol mat' súvis s jej osobnostnými tendenciami. Na základe uvedeného ako limit výskumu vnímame použitie dotazníka, ktorý hodnotí pocit osamelosti komplexne, pričom do d'alšieho výskumu odporúčame skúmat' osamelost' 
pomocou nástroja rozlišujúceho sociálnu a emocionálnu osamelost'. Niektorí autori (napr. Scharf, Wiseman, Farah, 2011) dokonca poukazujú na medzipohlavné rozdiely v prežívaní osamelosti, aj jej uvedených typov, preto by bolo vhodné v nasledujúcom výskume vziat' do úvahy v súvislosti s osamelost'ou aj pohlavie diet'at'a. Taktiež uvažujeme nad tým, že sebaposúdenie osobnosti matky nemusí úplne korešpondovat' s tým, ako jej osobnost' vníma a posudzuje jej diet’a, čo sa tiež mohlo odrazit’ na našich výsledkoch. Obohatenie budúceho výskumu o posúdenie osobnosti matky z pohl'adu diet'at'a by mohlo priniest' zaujímavé informácie o tom, nakol'ko sa sebaposúdenie osobnosti matky zhoduje s hodnotením jej osobnosti diet'at'om, a či práve to, ako diet’a vníma osobnost' matky súvisí s jeho osamelost'ou.

\section{ZÁVER}

Vo výskume sme sa zaoberali osamelost'ou diet'at'a v súvislosti sosobnost'ou matky, a to v ponímaní Learyho interpersonálnej teórie. Na osamelost' detí sme upriamili pozornost' z toho dôvodu, že osamelost' sa čoraz častejšie objavuje práve v období detstva a stala sa súčast'ou detských životov (Heinrich, Gullone, 2006). Za prínos štúdie považujeme objasnenie vzt’ahov osamelosti diet'at'a s jednotlivými interpersonálnymi tendenciami osobnosti matky, pričom odporúčame vskúmaní problematiky osamelosti diet’at'a, aj v súvislosti s osobnost’ou matky, pokračovat' na základe vyššie navrhnutých odporúčaní.

\section{LITERATÚRA}

Asher, S. R., Hymel, S., \& Renshaw, P. D. (1984). Loneliness in children. Child development, 55(4), 1456-1464.

Asher, S. R., \& Paquette, J. A. (2003). Loneliness and peer relations in childhood. Current Directions in Psychological Science, 12(3), 75-78.

Behrens, M. L. (1954). Child rearing and the character structure of the mother. Child Development, 25(3), 225-238.

Berguno, G., Leroux, P., McAinsh, K., \& Shaikh, S. (2004). Children's experience of loneliness at school and its relation to bullying and the quality of teacher interventions. The qualitative report, 9(3), 483-499.

Booth, R. (2000). Loneliness as a component of psychiatric disorders. Medscape General Medicine, 2(2), 1-7.

Brisch, K. H. (2012). Bezpečná výchova: budování jisté vztahové vazby mezi rodiči a dětmi. Praha: Portál.

Donaldson-Pressman, S., Pressman, R. M. (1994). The narcissistic family: Diagnosis and treatment. New York, US: Johnn Wiley \& Sons Inc.

Ernst, J. M., \& Cacioppo, J. T. (1999). Lonely hearts: Psychological perspectives on loneliness. Applied and preventive psychology, 8(1), 1-22.

Heinrich, L. M., \& Gullone, E. (2006). The clinical significance of loneliness: A literature review. Clinical psychology review, 26(6), 695-718.

Kožený, J., Ganický, P. (1976). Dotazník interpersonální diagnózy - ICL: Příručka. Bratislava: Psychodiagnostické a didaktické testy.

Kusý, P. (2015). Interpersonal behavior and music preferences of older school age children. In M. McGreevy, \& R. Rita, (Eds.), CER Comparative European Research 2015 (pp. 186 - 189). 
Kusý, P. (2018). Interpersonálne správanie a hudobný vkus v kontexte prosociálnosti v detskom veku. In J. Hrčová, B. Kováčová, \& M. Magová (Eds.). Expresívne terapie vo vedách o človeku 2018 (pp.17-27). Ružomberok: VERBUM.

LaForge, R., \& Suczek, R. F. (1955). The Interpersonal Dimension of Personality: III. An Interpersonal Check List 1. Journal of Personality, 24(1), 94-112.

Leary, T. (1957). Interpersonal diagnosis of personality: A functional theory and methodology for personality evaluation. New York: Ronald Press Co.

Macek, P. (2003). Adolescence. Praha: Portál.

Mikulincer, M., Shaver, P. R. (2017). Attachment in adulthood: structure, Dynamics and change. New York: The Guilford Press.

Nakonečný, M. (1998). Psychologie osobnosti. Praha: Academia.

Nolting, H. P., \& Paulus, P. (1992). Pädagogische Psychologie. Stuttgart: Kolhammer.

Oravcová, J. (2012). Vývinová psychológia. Banská Bystrica: Pedagogická fakulta, Univerzita Mateja Bela.

Perlman, D., Peplau, L. A., \& Peplau, L. (1984). Loneliness Research: A Survey of Empirical Findings. In L. A. Peplau, \& S. E. Goldston, (Eds.), Preventing the Harmful Consequences of Severe and Persistent Loneliness (pp. 13-46). Washingtton, D.C.:US Goverment Printing Office.

Pinquart, M., \& Sörensen, S. (2001). Influences on loneliness in older adults: A meta-analysis. Basic and applied social psychology, 23(4), 245-266.

Prekopová, J. (2004). Empatie, vcítení v každodenním životě. Praha: Grada Publishing.

Repetti, R. L., Taylor, S. E., \& Seeman, T. E. (2005). Rizikové rodiny: Sociálne prostredie rodín a duševné a fyzické zdravie potomkov. Empatia Bulletin, 12(4), 35-43.

Richaud De Minzi, M. C. (2006). Loneliness and Depression in Middle and Late Childhood: The Relationship to Attachment and Parental Styles. Journal of Genetic Psychology, 167(2), 189-210.

Rokach, A. (2004). Loneliness then and now: Reflections on social and emotional alienation in everyday life. Current Psychology, 23(1), 24-40.

Rönkä, A. R. (2017). Experiences of loneliness from childhood to young adulthood. Study of the Northern Finland Birth Cohort 1986. Oulu, Finland: University of Oulu.

Russell, D. W. (1996). UCLA Loneliness Scale (Version 3): Reliability, validity, and factor structure. Journal of personality assessment, 66(1), 20-40.

Russell, D., Peplau, L. A., \& Cutrona, C. E. (1980). The revised UCLA Loneliness Scale: Concurrent and discriminant validity evidence. Journal of Personality and Social Psychology, 39(3), 472-480.

Scharf, M., Wiseman, H., \& Farah, F. (2011). Parent-adolescent relationships and social adjustment: The case of a collectivistic culture. International Journal of Psychology, 46(3), 177-190.

Svoboda, M. (1999). Psychologická diagnostika dospělých. Praha: Portál.

Svoboda, M. (2010). Psychologická diagnostika dopělých. Praha: Portál

Širůček, J. (2001). Výchovné prístupy rodičov k det'om školského veku. In I. SarmánySchuller, (Eds.). Psychológia pre bezpečný svet (pp. 645-652). Bratislava: Stimul. 
Vališová, A. a kol. (1999). Autorita ve výchově: vzestup, pád, nebo pomalý návrat: učební text pro posluchače filozofické fakulty Univerzity Karlovy. Praha: Karolinum.

Varhol'áková, R. (2014). Činitele ovplyvňujúce úroveň emocionálnej inteligencie detí v predškolskom veku. Bratislava: Metodicko-pedagogické centrum.

Vágnerová, M. (2000). Vývojová psychologie: dětství, dospělost, stáří. Praha: Portál.

Výrost, J., Slaměník, I. (2001). Aplikovaná sociální psychologie. Praha: Grada Publishing.

Weiss, R. S. (1973). Loneliness: The experience of emotional and social isolation. Cambridge, MA: MIT Press.

Zilboorg, G. (1938). Loneliness. The Atlantic Monthly, 161(1), 45-54.

\section{PERSONALITY TENDENCIES OF A MOTHER AND LONELINESS OF A CHILD}

Abstract: The aim of the study was examination of relationship between interpersonal tendencies of mother's personality in context of Leary's interpersonal theory and loneliness of child. The research sample consisted of 60 mothers $\left(\mathrm{M}_{\mathrm{age}}=38.79 ; \mathrm{SD}_{\mathrm{age}}=\right.$ 3.22 ) and 60 children (32 girls, 28 boys, $\left.\mathrm{M}_{\text {age }}=10.19 ; \mathrm{SD}_{\text {age }}=0.77\right)$. For measuring personality tendencies of mother was used Interpersonal Checklist (ICL; Laforge, Suczek, 1955). Loneliness of child was measured by UCLA Loneliness Scale (Russell, Peplau, Cutrona, 1980). We found out negative relationship between autocratic and egocentric interpersonal tendency of mother's personality and loneliness of child. In the case of another interpersonal tendencies of mother, the relationship with loneliness of child was not found. We discuss these findings in the study.

Keywords: personality of a mother, interpersonal tendencies of personality, loneliness of a child 
